\title{
PENGARUH HASIL PERAMALAN PRODUKSI SEPATU KULIT LAKI-LAKI DI CV. PROHANA KABUPATEN TEGAL
}

\author{
Moh Zaynil Mustofa, Saufik Luthfianto, M Fajar Nurwildani \\ Program Studi Teknik Industri, Fakultas Teknik, Universitas Pancasakti, Tegal \\ moh.zaynil@gmail.com
}

\begin{abstract}
Abstrak
CV. Prohana adalah perusahaan yang memproduksi sepatu. Sebagai perusahaan sepatu, yang berbahan baku kulit sapi atau kambing terdapat beberapa masalah yang dihadapi CV. Prohana Tegal yaitu belum ada kesesuaian permintaan produk dengan hasil peramalan permintaan. Dari permasalahan tersebut maka penelitian ini bertujuan untuk mengetahui pengaruh peramalan terhadap produksi sepatu kulit laki-laki. Metode yang digunakan dalam penelitian ini adalah metode peramalan. Hasil dari penelitian ini adalah peramalan tersebut mempunyai pengaruh sebesar $95 \%$ terhadap permintaan produksi sepatu kulit laki-laki dan mempunyai korelasi sebesar 0.658 terhadap permintaan produksi sepatu kulit laki-laki.
\end{abstract}

Kata Kunci : Peramalan, korelasi, produksi, Sepatu Kulit

\section{PENDAHULUAN}

Dari data perusahaan bahwa masalah pada perusahaan belum ada kesesuaian permintaan produk dengan hasil peramalan permintaan yang mengakibatkan adanya gap hasil peramalan produksi dan permintaan sebesar 5,92\%, hal ini mengakibatkan kekurangan produksi yang berimbas pada keluhan konsumen karena ketidaktepatan analisa permintaan yang mengakibatkan menurunnya jumlah permintaan produk. Maka dari itu dibutuhkan proses peramalan atau prediksi untuk mengetahui dan menentukan seberapa besar produksi dimasa yang akan datang

Menurut Ilsan Nur Putra (2009) Metode peramalan dengan mempertimbangkan special event dapat meningkatkan akurasi ramalan jika dibandingkan dengan metode peramalan yang diterapkan oleh perusahaan saat ini. Peningkatan akurasi ramalan untuk produk Coca-Cola $193 \mathrm{ml}$, Sprite $200 \mathrm{ml}$, dan Frestea Jasmine $220 \mathrm{ml}$, Sprite $295 \mathrm{ml}$, Fanta Soda Water $295 \mathrm{ml}$, dan Frestea Jasmine $220 \mathrm{ml}$ masing-masing yaitu 4 persen, 9 persen, 12 persen, 4 persen, 3 persen, 3 persen. Natal dan Tahun baru merupakan pengaruh Special Event yang paling memiliki pengaruh yang signifikan dalam mempengaruhi permintaan untuk 6 varian produk ini yang didasari oleh oleh nilai indeks special event. Perencanaa produksi dengan menggunakan peramalan dengan mempertimbangkan special event dapat menghasilkan total penghematan untuk 6 varian produk sebesar 49.122.321,-/th yang merupakan 40 persen dari total biaya yang selama ini dikeluarkan oleh perusahaan. Kemudian menurut Puspitasari Kartika (2013) menghasilkan ramalan untuk semua produk menunjukkan bahwa hasil ramalan tertinggi pada bulan Juli dan Agustus, tepatnya yaitu pada 18 hari (satu bulan sebelum terjadinya hari raya Idul Fitri) dan 18 hari sebelum hari raya Idul Fitri (bulan terjadinya Idul Fitri). Pada penelitian Apostolos Kotsialos (2005) menjelaskan bahwa pada peramalan jangka menengah ke jangka panjang adalah di rancang untuk meramalkan tenaga kerja sehingga dari ketiga penelitian ini dapat diambil kesimpulan bahwa metode peramalan dengan mempertimbangkan special event dapat meningkatkan akurasi ramalan dan dengan peramalan jangka panjang menghasilkan ramalan tenaga kerja.

Dari ketiga penelitian diatas didapatkan perbedaan yang bisa dikaji dalam membahas tentang permasalahan yang dihadapi CV. Prohana Tegal yaitu besarnya pengaruh antara peramalan dan proses produksi sehingga dapat memenuhi permintaan konsumen.

\section{METODE PENELITIAN}

Metode yang digunakan dalam penelitian ini menggunakan metode peramalan dengan analisa regresi dan korelasi dengan objek penelitian di CV. PROHANA Kabupaten Tegal. 


\section{HASIL DAN PEMBAHASAN}

A. Hasil penelitian

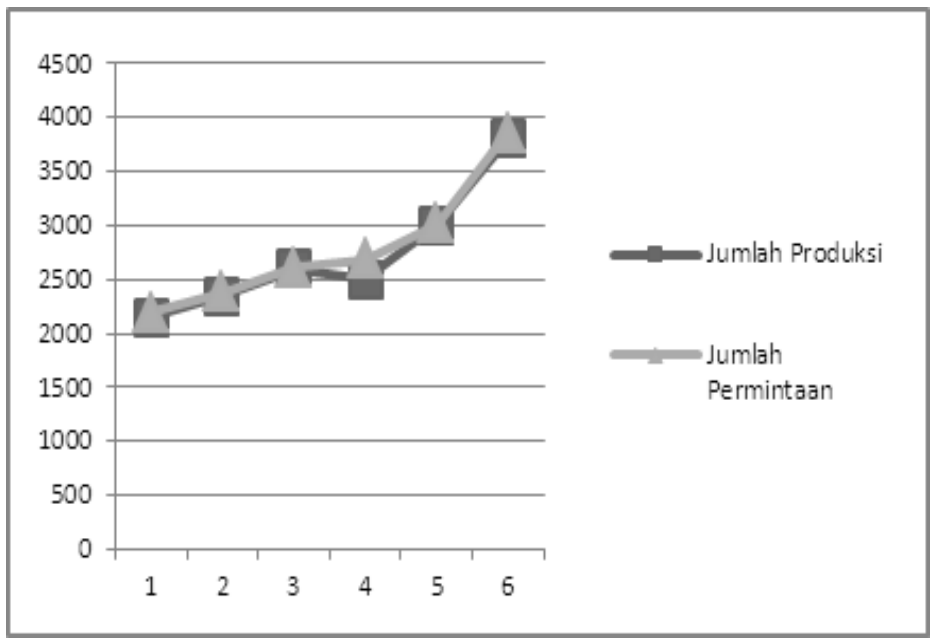

Gambar 1. Grafik antara jumlah produksi dan permintaan produksi

Untuk mengetahui keakuratan perhitungan dalam produksi digunakan metode peramalan dilakukan berdasarkan plot data permintaan. Dapat dilihat pada gambar 1 Grafik antara jumlah produksi dan permintaan produksi. Dari hasil perhitungan kemudian dibandingkan untuk melihat metode yang terbaik, seperti yang terlihat pada tabel dibawah ini:

Tabel 1. Perbandingan MAD, MSE dan MAPE

\begin{tabular}{c|c|c|c|c|c}
\hline & $\begin{array}{l}\text { Average 3 } \\
\text { Bulan }\end{array}$ & $\begin{array}{c}\text { Average 5 } \\
\text { Bulan }\end{array}$ & $\begin{array}{c}\text { Weiht Moving } \\
\text { Average }\end{array}$ & $\begin{array}{c}\text { Exp. Smoothing } \\
\text { (alpha =0.5) }\end{array}$ & $\begin{array}{c}\text { Exp. Smoothing } \\
\text { (alpha =0.9) }\end{array}$ \\
\hline MAD & 736,41 & 933,24 & 849,44 & 622,63 & 477,41 \\
MSE & 840908,4 & 1078815 & 1076596 & 630230,3 & 475749,3 \\
MAPE & 0,31 & 0,39 & 0,36 & 0,26 & 0,2 \\
\hline
\end{tabular}

Terlihat pada tabel diatas, metode peramalan yang memiliki MAD, MSE dan MAPE terkecil adalah Exponential Smoothing 0,9. Maka data yang diambil adalah hasil peramalan dari metode Exponential Smoothing 0,9.

B. Pembahasan

1. Uji Normalitas Data Dengan Kolmogrov Smirnov

Tabel 2. Uji Normalitas Data

\begin{tabular}{|c|c|c|}
\hline & & Aktual \\
\hline N & & 54 \\
\hline Normal Parameters $^{a}$ & Mean & 2571.11 \\
\hline & Std. Deviation & 860.527 \\
\hline Most Extreme Differences & Absolute & .136 \\
\hline & Positive & .136 \\
\hline & Negative & -.090 \\
\hline Kolmogorov-Smirnov Z & & .996 \\
\hline Asymp. Sig. (2-tailed) & & .274 \\
\hline distribution is Nor & & \\
\hline
\end{tabular}

Sumber : Data Diolah Menggunakan SPSS 
Pada kolom variabel aktual terdapat nilai kolmogrov-smirnovZ $=0,996$ dengan probabilitas 0,274 . Persyaratan data disebut normal jika probabilitas atau $\mathrm{P}>0,05$ pada uji normalitas dengan kolmogrov smirnovZ. Oleh karena nilai $\mathrm{P}=0,274$ atau $\mathrm{P}>0,05$, maka memenuhi syarat uji normalitas.

2. Uji Homogenitas Varian

Tabel 3. Uji Homogenitas varian

\begin{tabular}{|l|l|l|l|l|}
\hline & Levene Statistic & df1 & df2 & Sig. \\
\hline Data Based on Mean & .224 & 1 & 106 & .637 \\
Based on Median & .184 & 1 & 106 & .669 \\
Based on Median and with adjusted df & .184 & 1 & 105.950 & .669 \\
Based on trimmed mean & .229 & 1 & 106 & .633 \\
\hline
\end{tabular}

Sumber : Data diolah menggunakan SPSS

Pada out put test of homogenity of variance angka singnifikansi yang ada adalah untuk probabilitas based of mean $=0,637$, untuk based of median $=0,669$, probabilitas based on median and with adjusted $\mathrm{df}=0,669$, dan probabilitas based on trimmed mean $=0,633$, oleh karena probabilitas $>0,05$ maka dapat diketahui bahwa data aktual memiliki varian yang homogen, atau atau data berasal dari populasi-populasi dengan varian sama.

3. Asumsi Klasik Regresi Heteroskedastisitas

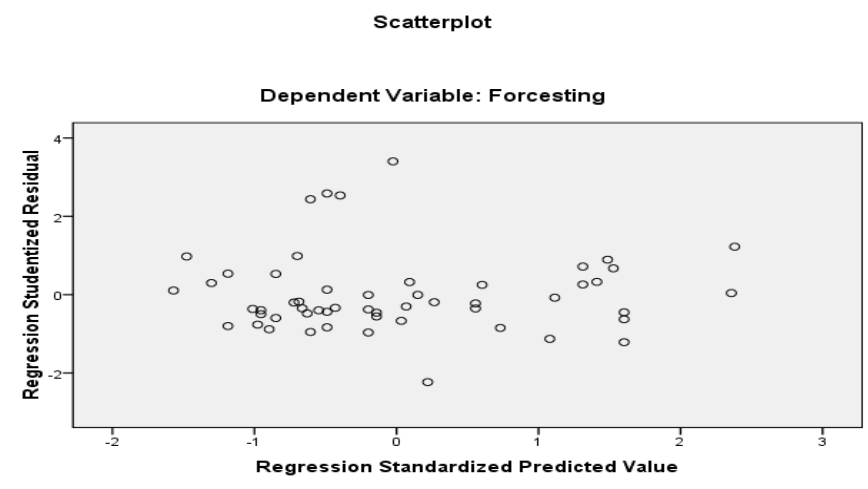

Gambar 2. Asumsi Klasik regresi Heterokedastisitas Sumber : Data Diolah Menggunakan SPSS

Suatu regresi dikatakan terdeteksi heteroskedastisitas-nya apabila diagram pencar residual membentuk pola tertentu. Tampak pada output di atas diagram pencar residual tidak membentuk suatu pola tertentu. Kesimpulanya, regresi terbatas dari kasus heteroskedastisitas dan memenuhi pesyaratan asumsi klasik tentang heteroskedastisitas.

4. Asumsi Klasik Regresi Tentang Multi-kolineritas

Tabel 4. Uji multikolineritas

\begin{tabular}{|l|l|l|l|l|l|}
\hline \multirow{2}{*}{ Model } & \multicolumn{3}{|c|}{ Correlations } & \multicolumn{2}{c|}{ Collinearity Statistics } \\
\cline { 2 - 6 } & Zero-order & Partial & Part & Tolerance & VIF \\
\hline 1 Forcesting & .658 & .658 & .658 & 1.000 & 1.000 \\
\hline
\end{tabular}

a. Dependent Variable: Aktual

Sumber : Data diolah menggunakan SPSS 
Suatu regresi dikatakan terdeteksi multikolineritas apabila nilai VIF menjauhi 1 pada output coeffecient. Tampak pada coeffecient kebetulan VIF $=1.000$ dan tolerance $=1.000$. baik VIF maupun tolerance sama dengan 1 sehingga model regresi terdeteksi multikolineritas. Kesimpulanya, sebenarnya model regresi diatas belum memenuhi persyaratan asumsi klasik tentang multikolineritas.

5. Asumsi Klasik Regresi Tentang Otokolerasi

Tabel 5. uji asumsi klasik regresi otokorelasi

\begin{tabular}{|l|l|l|l|l|l|}
\hline Model & R & R Square & Adjusted R Square & Std. Error of the Estimate & Durbin-Watson \\
\hline 1 & $.658^{\mathrm{a}}$ & .433 & .423 & 621.68341 & 1.223 \\
\hline
\end{tabular}

Sumber : Data Diolah Menggunakan SPSS

Kolom durbin watson (D-W) pada model summary menunjukan D-W $=1,223$. D$\mathrm{W}$ tabel pada $\mathrm{P}=0,05, \mathrm{~N}=54$ dan $\mathrm{K}$ (jumlah variabel bebas) $=2$ adalah $\mathrm{dL}=0,51$ (interpolasi dari dL tabel pada $\mathrm{N}=54$ yaitu 0,95 ) $\mathrm{dU}=0,82$ (interpolasi dari $\mathrm{dU}$ tabel pada $\mathrm{N}=54$ yaitu 1,54). Penentuan pengambilan keputusan Jika $\mathrm{D}-\mathrm{W}>\mathrm{dU}$, maka tidak ada kolerasi. Jika D-W $<\mathrm{dL}$, maka terjadi kolerasi. Jika $\mathrm{dL}<\mathrm{D}-\mathrm{W}<\mathrm{dU}$, maka tidak dapat dideteksi apakah terjadi otokolerasi atau tidak. Oleh karena D-W hitung $=1,223$, maka D-W $>d U>d L$. Dengan demikian dapat diputuskan tidak terjadi otokolerasi, atau model regresi memenuhi persyaratan asumsi klasik tentang otokolerasi.

6. Uji Asumsi Klasik Regresi Linearitas

Dari perhitungan menghasilkan nilai $\mathrm{F}=0,923$ dengan nilai $\mathrm{P}=0,589$. Baik Forecesting dengan Aktual memiliki nilai $\mathrm{P}>0,05$ pada deviation from linearity sehingga dapat dibuktikan bahwa pada taraf kepercayaan 95\% tidak terjadi penyimpangan signifikan terhadap linearitas.

Dari hasil perhitungan data memenuhi asumsi klasik linearitas sebagai prasyarat analisis regresi.

a. Regresi

Tabel 6. Koefisien Regresi

\begin{tabular}{|c|c|c|c|c|c|}
\hline \multirow[b]{2}{*}{ Model } & \multicolumn{2}{|c|}{ Unstandardized Coefficients } & \multirow{2}{*}{\begin{tabular}{|c} 
Standardized Coefficients \\
Beta
\end{tabular}} & \multirow[b]{2}{*}{$\mathrm{t}$} & \multirow[b]{2}{*}{ Sig. } \\
\hline & B & Std. Error & & & \\
\hline 1 (Constant) & 918.701 & 268.805 & & 3.418 & .001 \\
\hline Aktual & .626 & .099 & .658 & 6.307 & .000 \\
\hline
\end{tabular}

a. Dependent Variable: Forcesting

Sumber : Data Diolah Menggunakan SPSS

Pada ANOVA, Nilai $\mathrm{F}=39,782$ dengan $\mathrm{p}=0,000$. Oleh karena $\mathrm{p}<0,05$ maka regresi dapat dipakai untuk memprediksi produksi.

Pada coefficients Nilai B constant 918,701 menyatakan bahwa jika aktual diabaikan, maka forcesting adalah 918,701 unit. Nilai B aktual 0,626 menyatakan bahwa produksi akan meningkat sebanyak 0,626 unit. Berdasarkan nilai B constatn dan nilai B aktual, maka dapat dibuat persamaan regresi :

$$
\mathrm{Y}=\mathrm{a}+\mathrm{bX}=918,701+0,626 \mathrm{X}
$$

Nilai t hitung pada aktual adalah 6,370. Pada derajat bebas $(\mathrm{df})=\mathrm{N}-2=52-2=$ 50, nilai t tabel pada taraf kepercayaan 95\% (signifikansi 5\%) adalah 1,676 sehingga dapat diperhatikan pada gambar 2 Daerah Penolakan Dan Penerimaan $\mathrm{HO}$ 


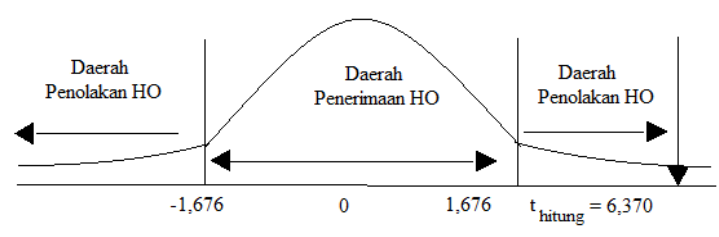

Gambar 3. Daerah Penolakan dan Penerimaan Ho

Oleh karena $\mathrm{t}$ hitung lebih besar dari $\mathrm{t}$ tabel, maka diputuskan bahwa koefesien regresi signifikan, atau aktual berpengaruh terhadap forcesting secara signifikan pada taraf kepercayaan 95\%. Probabilitas $=0,000$ atau P $<$ 0,05 , berarti koefesien regresi signifikan, atau aktual berpengaruh terhadap forcesting secara signifikan pada taraf kepercayaan 95\% (kegunaan $\mathrm{p}$ pada uji $\mathrm{t}$ adalah sama, yaitu sebagai dasar pengambilan keputusan signifikan tidaknya koefesien regresi).

b. Kolerasi

Tabel 7. Correlations

\begin{tabular}{|ll|r|r|}
\hline & & Aktual & Forcesting \\
\hline Aktual & Pearson Correlation & 1 & $.658^{\text {*** }}$ \\
& Sig. (2-tailed) & & .000 \\
& $\mathrm{~N}$ & 54 & 54 \\
\hline Forcesting & Pearson Correlation & $.658^{\text {*** }}$ & 1 \\
& Sig. (2-tailed) & .000 & \\
& $\mathrm{~N}$ & 54 & 54 \\
\hline
\end{tabular}

**. Correlation is significant at the 0.01 level (2-tailed).

sumber : data diolah menggunakan spss

Pada pearson correlation terlihat angka 0,658 yang menunjukan kolerasi memiliki nilai $\mathrm{r}=0,721$, oleh karena kolerasi antara aktual dan forcesting tersebut memiliki nilai $\mathrm{r}>0,6$ maka bisa disimpulkan bahwa kolerasi tersebut merupakan kolerasi yang kuat.

Dari hasil korelasi yang kuat diatas maka hasil peramalan metode eksponential smoothig 0,9 dapat menjadi acuan untuk untuk produksi sepatu sehingga pada penerapan hasil peramalan gap yang terjadi antara produksi dan permintaan produk berkurang menjadi $1,9 \%$.

\section{KESIMPULAN}

Dari hasil perhitungan dan analisa yang telah dilakukan dapat ditarik kesimpulan sebagai berikut:

1. Dari hasil perhitungan maka kita didapatkan pengaruh hasil peramalan terhadap proses produksi sebesar $95 \%$ dan mempunyai korelasi sebesar 0.658. Maka dapat disimpulkan peramalan tersebut mempunyai korelasi yang cukup kuat dengan data aktual.

2. Dari hasil penerapan metode eksponential smoothing 0,9 pada produksi menghasilkan berkurangnya gap sebesar $1,9 \%$.

\section{DAFTAR PUSTAKA}

Kartika, puspitasari, dkk, 2013, Prediksi Penjualan di Perusahaan Ritel dengan Metode Peramalan Hirarki berdasarkan Model Variasi Kalender,

Khairani, Sofyan Diana, 2013, Perencanaan dan Pengendalian Produksi, Graha Ilmu, Yogyakarta. 
Kotsialos Apostolos, Markos Papageorgiou And Antonios Poulimenos. 2005. Long-Term Sales Forecasting Using Holt-Winters and Neural Network Methods. Journal of Forecasting 24, 353-368 (2005) Technical University of Crete, Greece

Markidakis, Spyros, dkk, 1983, Forecasting, Penerbit Erlangga, Jakarta

Putra, Ilsan Nur. I Nyoman Pujawan. Niniet Indah Arvitrida, 2009, Peramalan Permintaan Dan Perencanaan Produksi Dengan Mempertimbangkan Special Event Di PT. Coca-Cola Bottling Indonesia (PT. CCBI) Plant Pandan

Sahli, Muhamad, 2013, Penerapan Metode Exponential Smothing Dalam Sistem Informasi Pengendalian Bahan Baku, Universitas Muria Kudus

Susanto, Septian Pim Hadi, 2008, Pengaruh Pengendalian Produksi Terhadap Produk Kursi Rotan Paada CV. Mutiara Rotan, Cirebon 